\title{
IMPACT OF HUMAN INTERVENTION AND SEA LEVEL RISE ON WATER- LOGGING SCENARIOS INSIDE POLDERS-24 AND 25 OF BANGLADESH
}

\author{
Jamal M Haider ${ }^{1}$, Haque M Aminul*¹, Hossain Md Jahid ${ }^{1}$, and Haque Anisul ${ }^{\mathbf{2}}$ \\ ${ }^{1}$ Water Resources Planning Organization, 72 Green Road, Dhaka121, Bangladesh. \\ 2 Institute of Water and Flood Management, BUET, Dhaka1000, Bangladesh.
}

Received: 23 May 2021

Accepted: 20 November 2021

\begin{abstract}
Coastal region of Bangladesh possesses a fragile ecosystem and is exposed to hazards like cyclones, floods, storm surges, and water-logging. A detail understanding on the impact of water-logging due to various natural, man-made and climate change scenarios is still lacking. Considering this research gap, the present research is aimed to study impacts of these scenarios inside polders-24 and 25 which are situated on the western part of the coastal region. In this Study as natural scenario, sedimentation in the Hari River; as man-made scenario, new polders in the south-central region and as SLR scenario, an extreme sea level rise of $1.48 m$ are considered. Long-term satellite images are analyzed, and numerical model is applied in the study area. The result shows that water-logging is more acute inside polder-25 compared to polder-24. Sedimentation in Hari River aggravates the water-logging condition. Dredging in Hari River does improve the situation.
\end{abstract}

Keywords: Climate Chang, Dredging, Polder, Sea Level Rise, Sedimentation, Water-Logging

\section{INTRODUCTION}

Water-logging is the dominant hazard in the south-west region of Bangladesh. Among the prevailing 32 hazards recognized by Bangladesh, water logging is considered as the key water resources challenge by Bangladesh Delta Plan 2100.Southwest coastal region of Bangladesh has a unique brackish water ecosystem comprising the districts of Satkhira, Khulna, Bagerhat and the southern part of Jessore. Large portion of this region is coastal wetland which is formed by the rivers flowing to the sea. This region possesses a fragile ecosystem and is exposed to a number of natural calamities like cyclones, floods, tidal surges, repeated water logging, and land erosion, degradation etc. All these hazards shaped the lives and livelihood patterns of people in the region. Among these hazards, water-logging is characterized as a long-duration hazard that may last for at least three months, and may prolong up to 8-9 months or even become perennial. The depth of flooding varies, according to the topography of the area, and can reach up to $3 \mathrm{~m}$. Technically, water-logging refers to a situation when the level of groundwater meets plants' root zone.

Water-logging in the western floodplain of the system came into existence during mid 80's. In earlier decades before 1960s, as Bangladesh is located at the lowermost reaches of three mighty river systems- Ganges, Brahmaputra and Meghna, low lying areas of coastal zone were frequently flooded by salt water during high tide (Islam et al, 2013). In order to increase agricultural production, a series of polders enclosing the low-lying coastal areas was built (BWDB, 2003). This polder system from Dutch experiences was not fruitful (masud et al., 2018) in the long run due to lack of consideration of geo-physical settings and hydro-morphological characters of the south-west region (Roy et al., 2017). There are several studies on effects of Climate Change on Polder system and hence the livelihood of the people inside the polder. Ali and Syfullah (2017) studied the impact of SLR on polder enclosed beel communities. They investigated the SLR impacts on human, natural, physical, financial and social dimension for three level of inundations in terms of resiliency and vulnerability. They found that the proper regulation of sluice gate has a role in improving the inundation situation.

The presence of coastal polders de-linked the flood plain. Due to confinement of the rivers by the polders, rivers gradually started to be silted up one after another and created water-logging in the floodplain, and by 1980s, many of the river beds became higher than the adjacent crop lands and vast area under the polders became permanently water logged, rendering large tract of land uncultivable (Leender, 2013). Sediment could not be deposited in the flat tidal plain due to polder embankment and began to deposit on the river bed. As a result, flat 
sluice gate became inoperative; water in the polders could not flow out. Through these processes, more than one hundred thousand hectares of land became water-logged in a gradual process. One of the problems with water logging is to define the limits of water logging - a seasonal drainage problem - as distinct from perennial water bodies in south-western region of Bangladesh. One way to do this is to compare satellite images at different times of the year/hydrological cycle.

Besides these natural and man-made causes, climate change also aggravates the water logging problem in this region. Polders are generally believed to cause water-logging inside the protected land due to sedimentation in the peripheral rivers. But it is still unknown how these polders affect re-distribution of coastal floodplain sedimentation in the region. A detail understanding of the process of water-logging due to sedimentation of peripheral rivers is also lacking (WARPO and IWFM, 2019). Considering this research gap, the objectives of the paper are (1) to identify the water-logging process in the study area by analyzing satellite images and numerical model (2) to analyse the impact of sedimentation in the peripheral rivers on the water logging process along with the SLR scenarios.

\section{METHODOLOGY}

\subsection{Study Area}

In the early $60 \mathrm{~s}, 1566 \mathrm{~km}$ of embankments with 282 sluice gates were constructed in the southwest region to reclaim all the tidal influence coastal areas that lay below the highest tide levels for periodic inundation by saline water for crop production. 21 vents Bhabadaha sluice gate was one of the important structures which is now the source of the pains for millions of people. Within 15 years of the construction of embankments, siltation started at the water entrance point of the sluice gates and rivers and canals bed height began to increase. As a result, first the Beel Dakatia inside polder 25 became water logged. Subsequently polder 24, 27 and 28 also became waterlogged one after another. In this paper, the study area is comprised with the areas of polders 24 and 25 . Four upazilas are within the polder area. These are: Phultala, Khan Jahan Ali, Dumuria from Khulna District and Keshabpur from Jessore district. The main river flowing in between these two polders are Hari River which largely dictates the drainage from the polders. Several depression (Locally named as beels) works as perennial water bodies within the polders. The study area is shown in Fig 1.

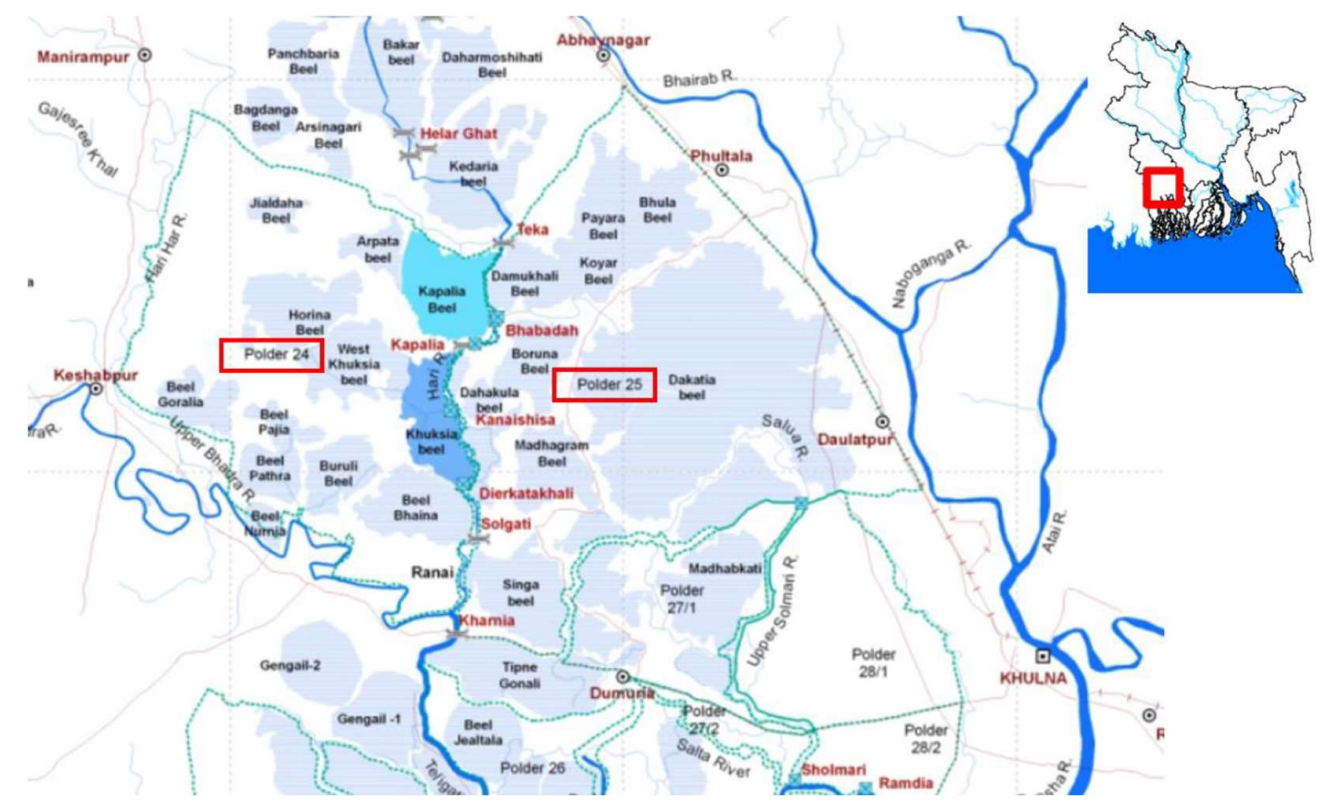

Figure 1: Study Area for Water Logging

\subsection{Data Collection and Model}

This research is conducted by considering natural, man-made and climate change scenarios to compute the water-logging process by analyzing satellite images and by applying numerical model. As study area for model 
application, polders 24 and 25 are selected. The flow module of Delft 3D modeling suite is applied to compute the water-logging inside polders 24 and 25. Delft3D is a integrated modelling suite, which simulates twodimensional (in either the horizontal or a vertical plane) and three-dimensional flow, sediment transport and morphology, waves, water quality and ecology and is capable of handling the interactions between these processes. FLOW module is the heart of Delft3D and is a multi-dimensional (2D or 3D) hydrodynamic (and transport) simulation programme which calculates non-steady flow and transport phenomena resulting from tidal and meteorological forcing on a curvilinear, boundary fitted grid or spherical coordinates. In 3D simulations, the vertical grid is defined following the so-called sigma coordinate approach or Z-layer approach. The MOR module computes sediment transport (both suspended and bed total load) and morphological changes for an arbitrary number of cohesive and non-cohesive fractions (Deltares). Both currents and waves act as driving forces and a wide variety of transport formulae have been incorporated. For the suspended load this module connects to the 2D or 3D advection-diffusion solver of the FLOW module; density effects may be taken into account. This model requires a detail description of river and canal network, road network, depression (Locally named as beel) and sluices that connects the main river with the polder domain inside. A detail of the waterlogging model that shows canal network, road network, sluices is shown in Fig -2.

Land topographic input in the model is provided from Digital Elevation Model (DEM) which is currently available at WARPO. For the river bathymetry, combinations of secondary and primary data are used. Secondary data are collected from BWDB and primary data in 294 locations in the rivers/estuaries of coastal zone are measured. Ocean bathymetry is provided from the open access General Bathymetric Chart of the Oceans (GEBCO).Channel plan forms are assumed to remain the same over the model simulation period. Similar assumption is made for channel bed level and floodplain levels of rivers / estuaries.

Model receives fluvial flows from three major rivers in the region - the Ganges, Brahmaputra and Upper Meghna. For all the scenario runs - model simulated daily discharges from INCA hydrological model (Whitehead et al., 2015) are used as discharge boundary conditions. Tidal forcing in the model is provided by sea surface elevation in the Bay of Bengal. For all the scenarios runs - model simulated hourly sea surface by GCMOS ocean model (Kay et al., 2015) is provided as the downstream sea level boundary. In micro-scale model, morphological changes are considered static (except subsidence) - so no additional sediment input is provided.

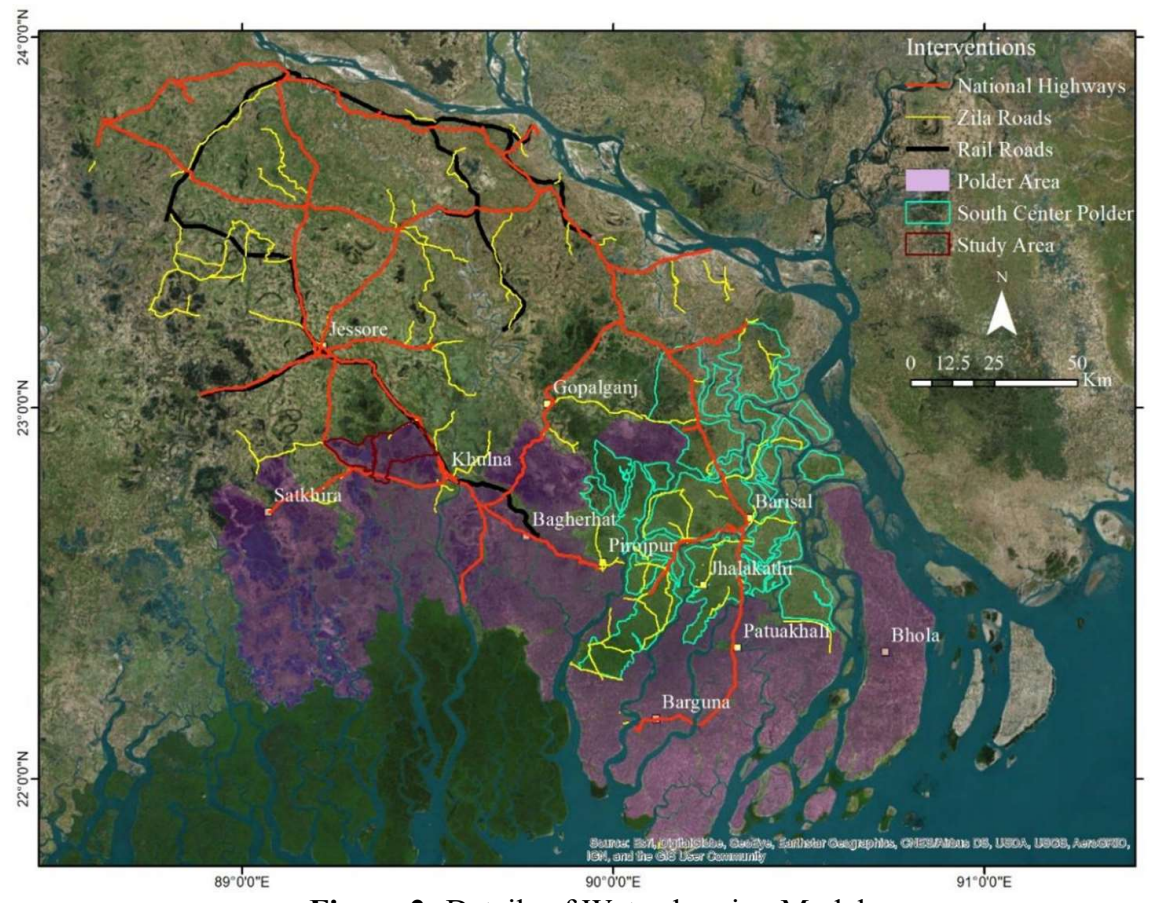

Figure 2: Details of Water-logging Model

As climate change scenario, eight different scenarios are constructed to analysis water-logging conditions in different combinations of morphological and climatic variables. Out of these 8 scenarios, 4 are for base condition and 4 are for future. Year 2000-2001 is used as the base year and Year 2100 as the future scenario. For endcentaury scenario, a sea level rise of $1.48 \mathrm{~m}$ is used as sea level condition and a warmer \& wetter climate is used 
as the climatic condition. A warmer and wetter climate increases precipitation in the upstream basins during the monsoon and affects the upstream discharges of the major the river systems. These combined effects are taken into considering during simulation of water-logging condition during end-century. Four base and future scenarios are constructed by considering (1) no intervention (base scenario) (2) sedimentation in the Hari River which is the main river system in the study region (3) dredging of the Hari River and (4) construction of 24 new polders in the south-central region. New polders in south-central region are introduced by considering the fact that this region is flooded during the sea level rise and currently there is no polder in this region.

\section{RESULTS AND DISCUSSION}

To identify the extent of inundation inside polders 24 and 25, model simulated result for the average flood year scenario of the year 2000 is compared with MODIS satellite images (which is also the base year in this study) which is shown in Fig.3.
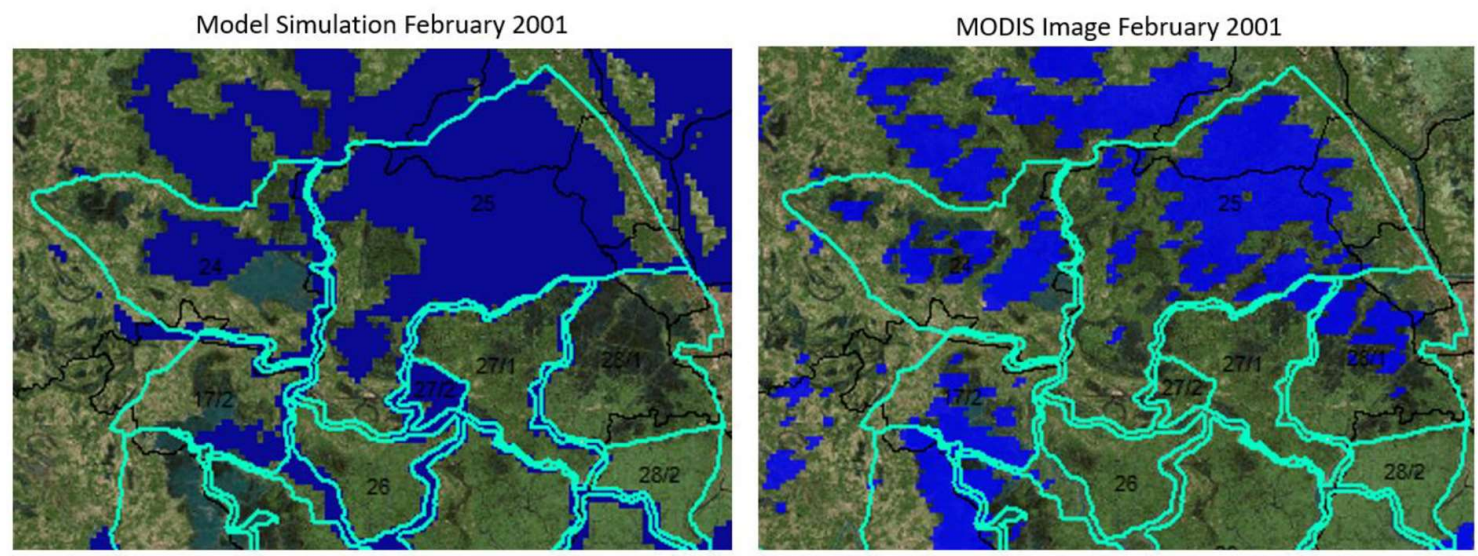

Figure 3: Comparison of inundation extent between model simulation (left) and MODIS Image (right) during dry season (February) of the year 2001. The comparison shows inundation inside polders 24 and 25.

Validated model is applied to simulate 8 different water-logging scenarios. Scenario descriptions and results from model simulations for each of the scenarios are described in Table-1. Results are also shown in Figures-4 (a- n).

Table 1: Model simulated result comprising 8 climate change scenarios using water logging model

\begin{tabular}{ll}
\hline Scenario no & Scenario Description \\
\hline 1 & Base scenario. \\
& Base condition is the \\
& average flood year 2000. \\
& Sea level rise is zero. The \\
& scenario is driven by the \\
& discharges of year 2000. \\
& To capture the complete \\
& drainage condition, model \\
& run is extended till March \\
& 2001.
\end{tabular}

Assumptions for the scenario
In this scenario, no physical
intervention is made. This is
the base scenario for years
$2000-2001$.

2000-2001.

Base scenario.

Sedimentation in the Hari River (which is the main river between polders 24 $\& 25)$ is considered in base condition.
This is the base scenario where sedimentation is introduced in the Hari River. It is assumed that sedimentation reach of the river has decreased conveyance which has a length of about $30 \mathrm{~km}$. The sedimentation has filled the river bed to a maximum of $1.5 \mathrm{~m}$. The sediment volume

\section{Results from the scenario} - Flooding is mainly concentrated in the depression region.

- Flooding is more pronounced inside polder-25 compared to polder-24.

- After drainage during the entire dry season, water-logged condition is observed in most of the depressions inside polders 24 $\& 25$.

Results are shown in Figure 4(a). - During monsoon, inundation inside polders $24 \& 25$ increases due to sedimentation of the Hari River.

- Sedimentation in Hari River aggravates the water-logging condition.

- Sedimentation mainly affects the region which is close to the Hari River. 


\begin{tabular}{|c|c|c|c|}
\hline Scenario no & Scenario Description & Assumptions for the scenario & Results from the scenario \\
\hline & & $\begin{array}{l}\text { that has deposited inside the } \\
\text { river is about } 6750 \text { ton. }\end{array}$ & Results are shown in Figure 4(b). \\
\hline 3 & $\begin{array}{l}\text { Base scenario. } \\
\text { Dredging in the Hari } \\
\text { River (which is the main } \\
\text { river between polders } 24 \\
\& 25 \text { ) is considered in } \\
\text { base condition. }\end{array}$ & $\begin{array}{l}\text { This is the base scenario } \\
\text { where Hari River is dredged to } \\
\text { improve the water-logged } \\
\text { condition. A total of } 30 \mathrm{~km} \\
\text { reach of the Hari River is } \\
\text { dredged to a depth of } 1.5 \mathrm{~m} \\
\text { from its present bed level. } \\
\text { Dredging is made uniformly } \\
\text { keeping the bed slope same } \\
\text { before and after dredged } \\
\text { condition. In this way, a total } \\
\text { of } 6750 \text { ton of soil is dredged } \\
\text { from the river bed. }\end{array}$ & $\begin{array}{l}\text { - During monsoon, inundation } \\
\text { inside polders } 24 \text { \& } 25 \text { decreases } \\
\text { when Hari River is dredged. } \\
\text { - Dredging in Hari River } \\
\text { improves the water-logging } \\
\text { condition. } \\
\text { - Dredging mainly affects the } \\
\text { region which is close to the Hari } \\
\text { River. } \\
\text { Results are shown in Figures } 4(\mathrm{c}) \\
\text { and } 4(\mathrm{~d}) \text {. }\end{array}$ \\
\hline 4 & $\begin{array}{l}\text { Base scenario. } \\
\text { New polders (SC polders) } \\
\text { are introduced in south- } \\
\text { central region in base } \\
\text { condition. }\end{array}$ & $\begin{array}{l}\text { In this scenario, new polders } \\
\text { are introduced in south-central } \\
\text { region in base condition. With } \\
\text { the introduction of new } \\
\text { polders in this region, the } \\
\text { south-central region will be } \\
\text { flood-free. But this } \\
\text { intervention shifts the flood } \\
\text { hazard to further west where } \\
\text { polders } 24 \text { and } 25 \text { (present } \\
\text { study area) are situated. Water } \\
\text { has not entered inside these } \\
\text { polders but affects the } \\
\text { flooding in surrounding } \\
\text { region. This might have some } \\
\text { impact on the water-logging } \\
\text { condition inside polders } 24 \\
\text { and } 25 \text {. }\end{array}$ & $\begin{array}{l}\text { - During monsoon, impact of SC } \\
\text { polders inside polders } 24 \& 25 \text { is } \\
\text { not visible. } \\
\text { - SC polders slightly aggravate } \\
\text { water-logging condition. This } \\
\text { shows SC polders mainly affect } \\
\text { drainage. } \\
\text { - Impact of SC polders are visible } \\
\text { close to eastern border of polder } \\
25 \text {. This border directly feels the } \\
\text { shift of flood hazard due to } \\
\text { construction of SC polders. } \\
\text { Results are shown in Figures } 4(\mathrm{e}) \text {, } \\
4(\mathrm{f}) \text { and } 4(\mathrm{~g}) \text {. }\end{array}$ \\
\hline 5 & $\begin{array}{l}\text { end-centaury scenario. } \\
\text { The snapshot selected for } \\
2100 \text { scenariois the year } \\
2088-2089 \text {. Sea level rise } \\
\text { is } 1.48 \mathrm{~m} \text {. Warmer and } \\
\text { wetter climate drives } \\
\text { increased inflow into the } \\
\text { system. }\end{array}$ & $\begin{array}{l}\text { This is the end-centaury } \\
\text { scenario where sea level rise is } \\
1.48 \mathrm{~m} \text { and flooding is driven } \\
\text { by a warmer and wetter } \\
\text { climate. The end-centaury } \\
\text { scenario is represented by } \\
\text { snapshot of the year 2088- } \\
\text { 2089. In this scenario, no } \\
\text { intervention is considered. }\end{array}$ & $\begin{array}{l}\text { Both the polders } 24 \& 25 \text { are } \\
\text { completely inundated. } \\
\text { - During dry season, inundation } \\
\text { depth decreases but the extent of } \\
\text { inundation remains the same. } \\
\text { - The entire region becomes } \\
\text { perennial water body. } \\
\text { - Result is shown in Figure } \\
4(\mathrm{~h}) \text {. }\end{array}$ \\
\hline 6 & $\begin{array}{l}\text { end-centaury scenario. } \\
\text { Sedimentation in the Hari } \\
\text { River is considered in } \\
\text { end-century. }\end{array}$ & $\begin{array}{l}\text { This is the end-centaury } \\
\text { scenario when the Hari River } \\
\text { is sedimented. Comparison } \\
\text { shows inundation patterns } \\
\text { during monsoon when Hari } \\
\text { River is sedimented and when } \\
\text { it is not sedimented. This } \\
\text { comparison is for end-century. } \\
\text { This shows impact of } \\
\text { sedimentation of Hari River } \\
\text { on water-logging in end- } \\
\text { century. }\end{array}$ & $\begin{array}{l}\text { - Impact of sedimentation is not } \\
\text { visible in monsoon. The entire } \\
\text { area is completely inundated. } \\
\text { - Water-logging remains almost } \\
\text { same both for with and without } \\
\text { sedimentation of the Hari River. } \\
\text { Results are shown in Figures 4(i) } \\
\text { and } 4(j) \text {. }\end{array}$ \\
\hline 7 & $\begin{array}{l}\text { end-centaury scenario. } \\
\text { Dredging in the Hari } \\
\text { River is considered in } \\
\text { end-centaury scenario. }\end{array}$ & $\begin{array}{l}\text { This is the future scenario } \\
\text { where Hari River is dredged to } \\
\text { improve the water-logged } \\
\text { condition. }\end{array}$ & $\begin{array}{l}\text { - Impact of dredging is not visible } \\
\text { in monsoon. The entire area is } \\
\text { completely inundated. } \\
\text { - Water-logging remains almost }\end{array}$ \\
\hline
\end{tabular}




\begin{tabular}{|c|c|c|c|}
\hline Scenario no & Scenario Description & Assumptions for the scenario & Results from the scenario \\
\hline & & $\begin{array}{l}\text { Comparison of inundation } \\
\text { patterns during monsoon when } \\
\text { Hari River is not dredged and } \\
\text { when it is dredged is shown. } \\
\text { This comparison is for end- } \\
\text { century. }\end{array}$ & $\begin{array}{l}\text { same both for with and without } \\
\text { dredging of the Hari River. } \\
\text { Results are shown in Figures } 4(\mathrm{k}) \\
\text { and } 4(1) \text {. }\end{array}$ \\
\hline 8 & $\begin{array}{l}\text { end-centaury scenario. } \\
\text { New polders in south- } \\
\text { central region are } \\
\text { considered in end- } \\
\text { century. }\end{array}$ & $\begin{array}{l}\text { In this scenario, new polders } \\
\text { are introduced in south-central } \\
\text { region in end-century. At } \\
\text { present, there is no polder in } \\
\text { south-central region and the } \\
\text { region will be flooded during } \\
\text { sea level rise } \\
\text { Comparison of inundation } \\
\text { patterns during monsoon when } \\
\text { SC polders is absent and when } \\
\text { it is present is shown. This } \\
\text { comparison is for end-century. }\end{array}$ & $\begin{array}{l}\text { - Impact of SC polders is not } \\
\text { visible in monsoon. The entire } \\
\text { area is completely inundated. } \\
\text { - Water-logging remains almost } \\
\text { same both for with and without } \\
\text { SC polders. } \\
\text { Results are shown in Figures } 4(\mathrm{~m}) \\
\text { and } 4(\mathrm{n}) \text {. }\end{array}$ \\
\hline
\end{tabular}
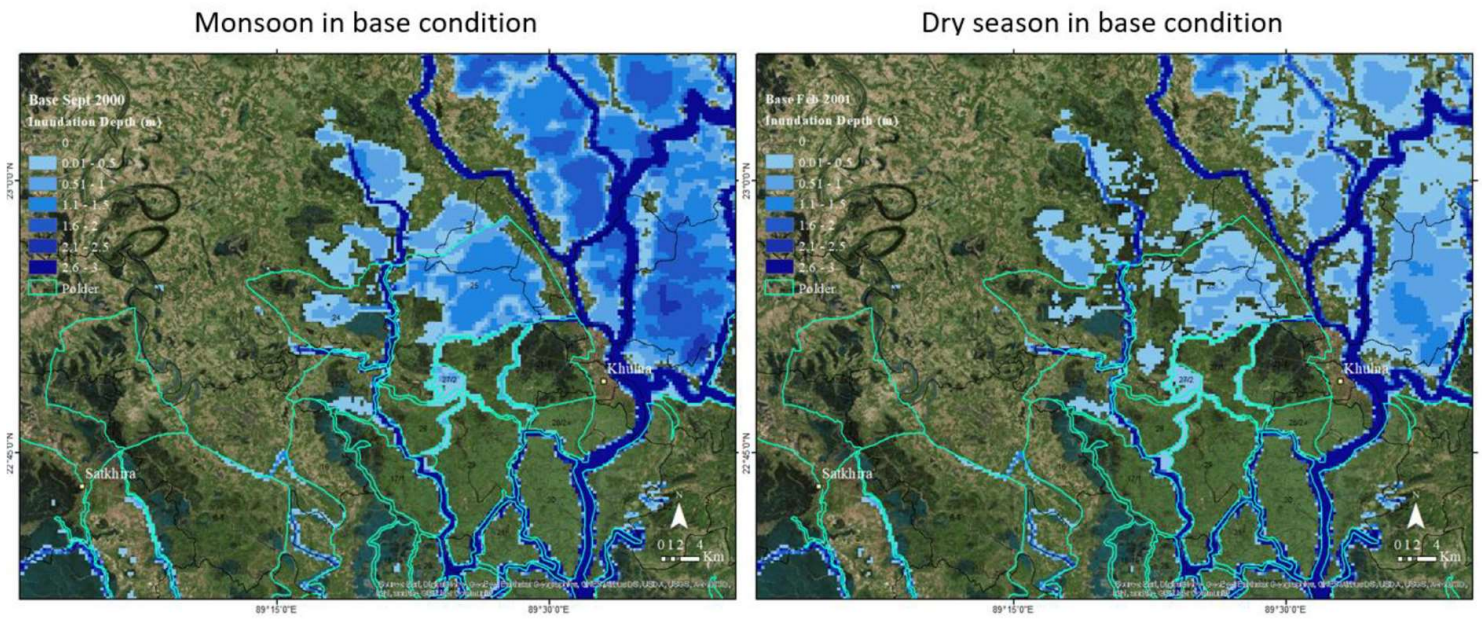

Figure 4(a): Scenario-1: Inundation in base condition during monsoon and dry season

Monsoon in base condition without sedimentation

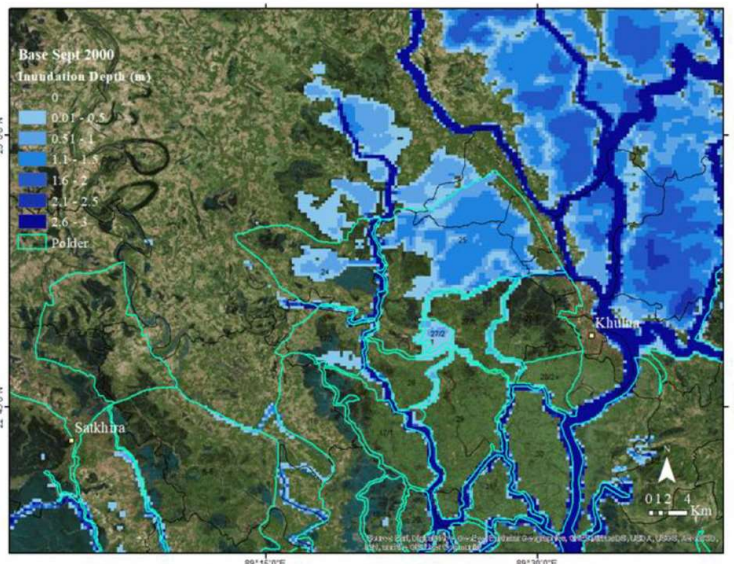

Monsoon in base condition with sedimentation

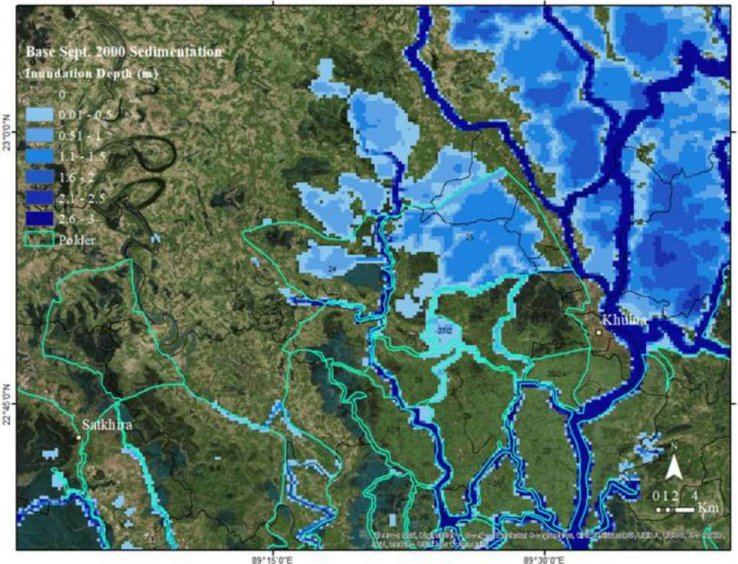

Figure 4(b): Scenario-2: Inundation during monsoon when Hari River is not sedimented (left) and when it is sedimented (right). This scenario is for base condition. 

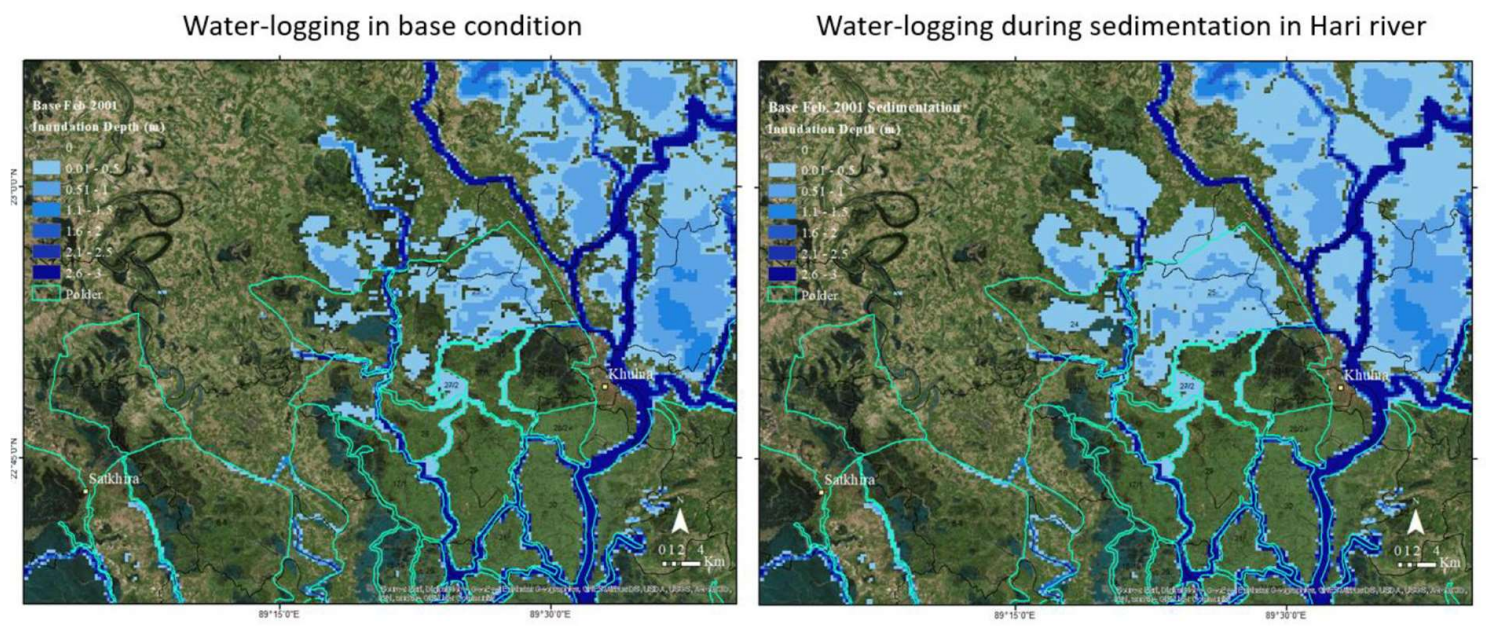

Figure 4(c): Scenario-3: Water-logging in the study area. Water-logged condition is created during dry season of base condition. The left image shows when there is no sedimentation in Hari River.The right image shows when Hari River is sedimented.
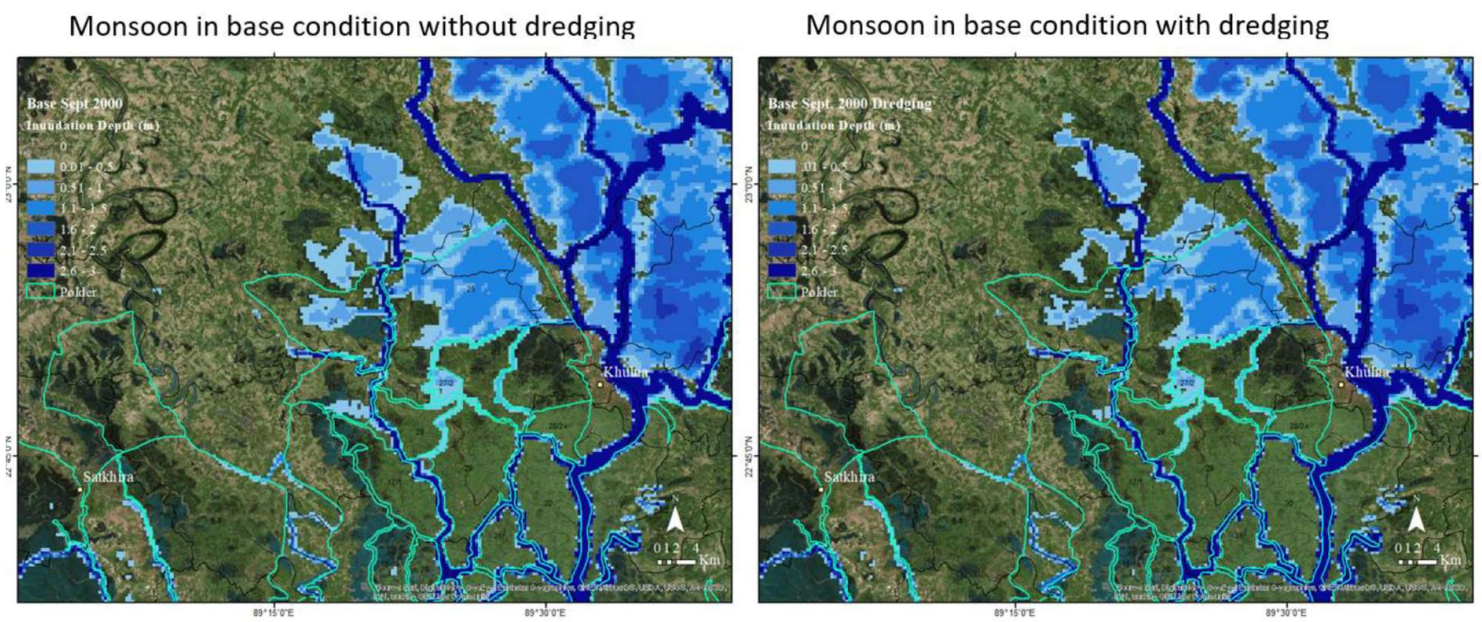

Figure 4(d): Scenario-3: Inundation during monsoon when Hari River is not dredged (left) and when it is dredged (right). This is for the base condition.

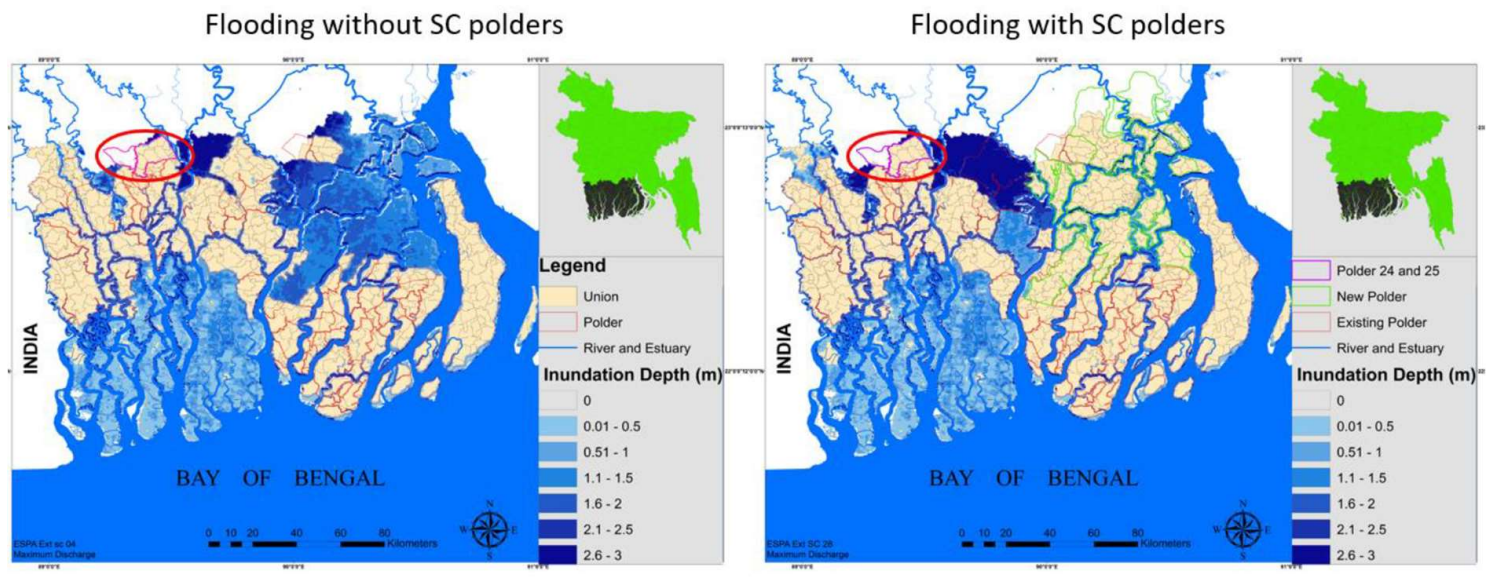

Figure 4(e): Scenario-4: Change of flooding pattern due to construction of new polders in south-central-region. The red circled region shows polders $24 \& 25$, which is the study area of present study. 

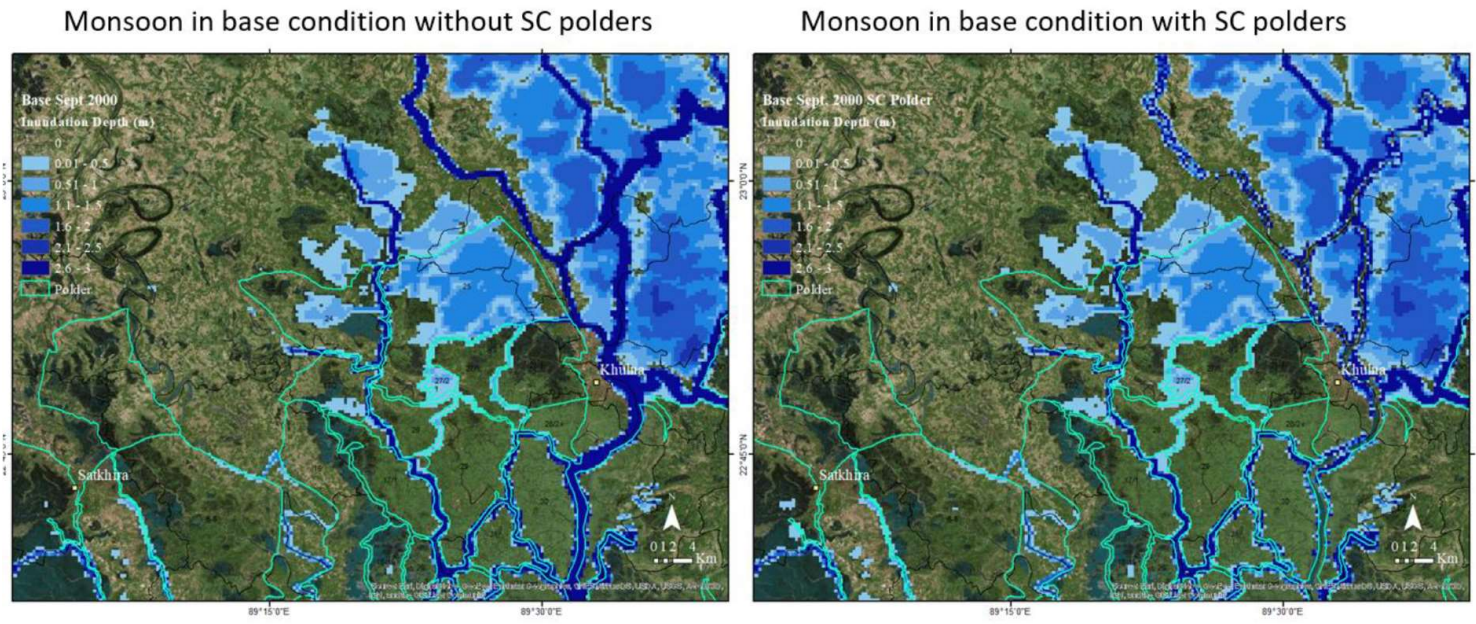

Figure 4 (f): Scenario-4: Inundation during monsoon without SC polders (left) and with SC polders (right). This scenario is for base condition.

Water-logging in base condition

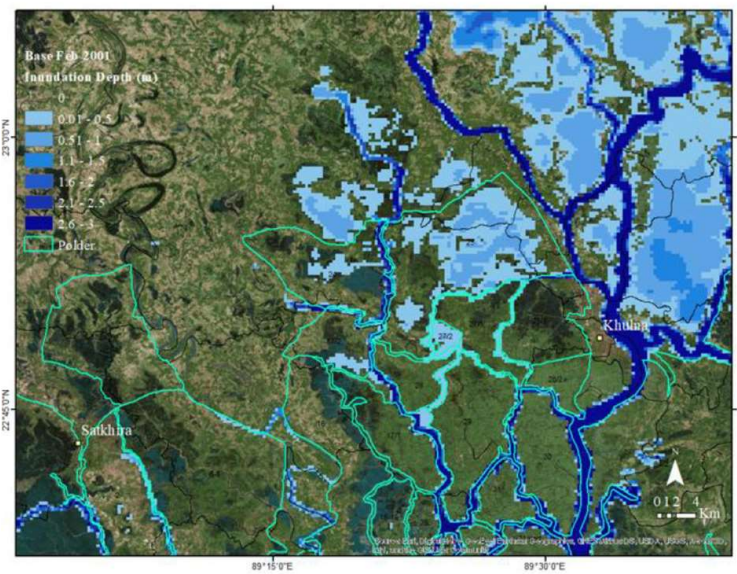

Water-logging with SC polders

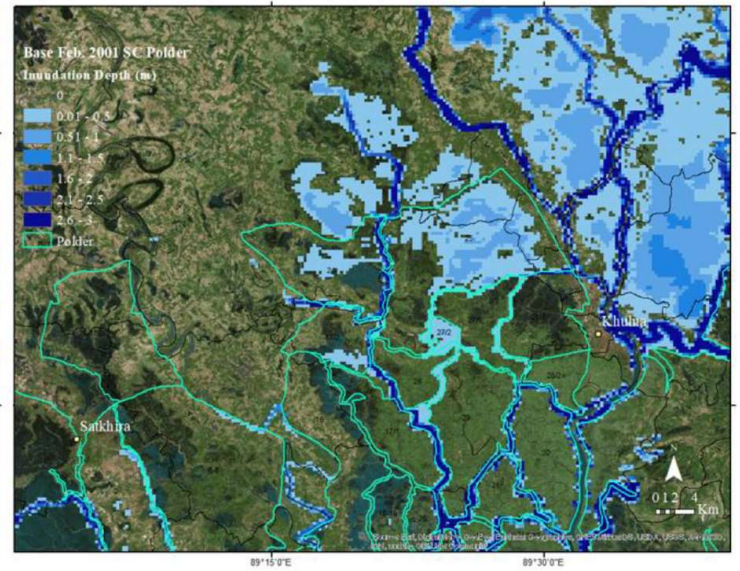

Figure 4 (g): Scenario-4: Water-logging in the study area. Water-logged condition is created during dry season. The left image shows without SC polders. The right image shows with SC polders.

Monsoon in end-century

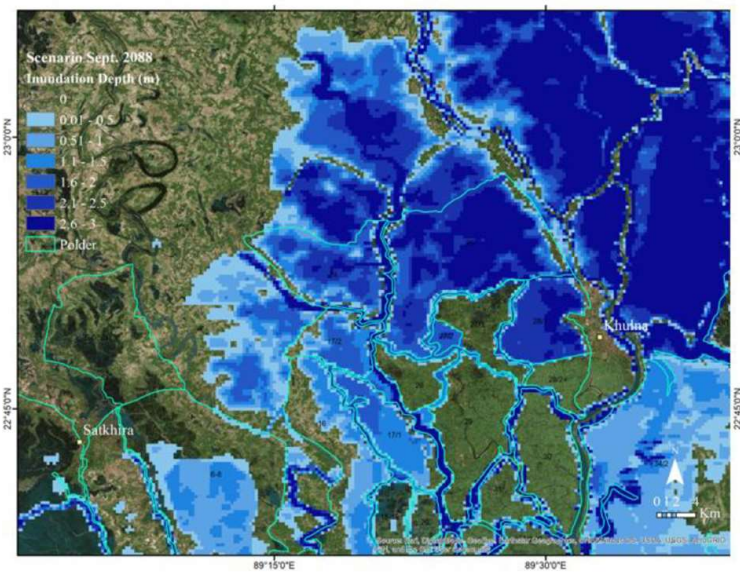

Dry season in end-century

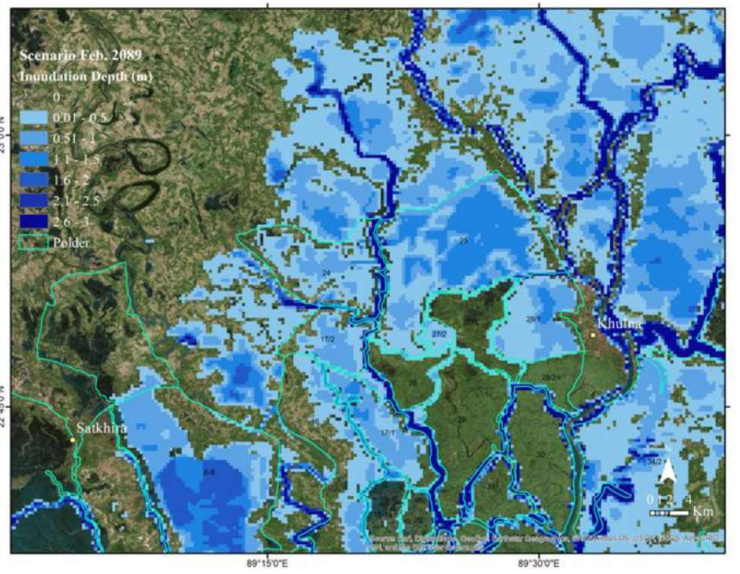

Figure 4(h): Scenario-5: Inundation in end-centaury scenario during monsoon and dry season 
Water-logging in end-century without sedimentation

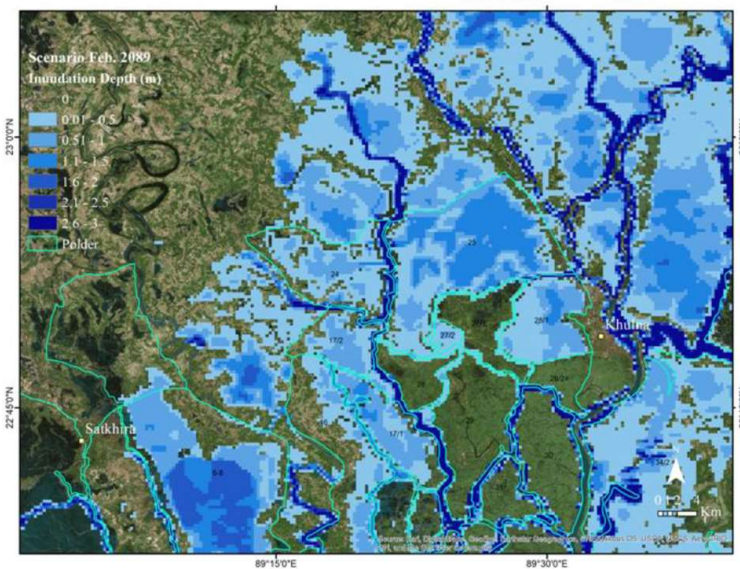

Water-logging in end-century with sedimentation

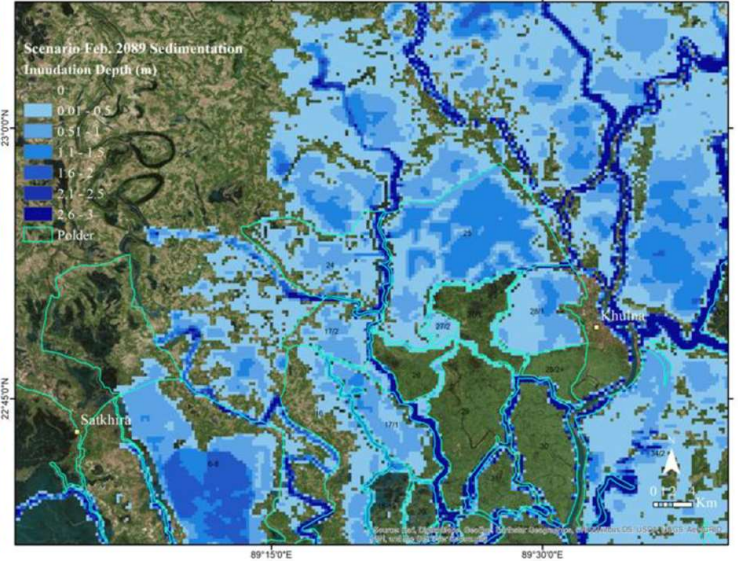

Figure 4(j): Scenario-6: Water-logging in the study area. Water-logged condition is created during dry season. The left image shows when there is no sedimentation in Hari River. The right image shows when Hari River is sedimented. The scenario is for end-century.

Monsoon in end-century without dredging

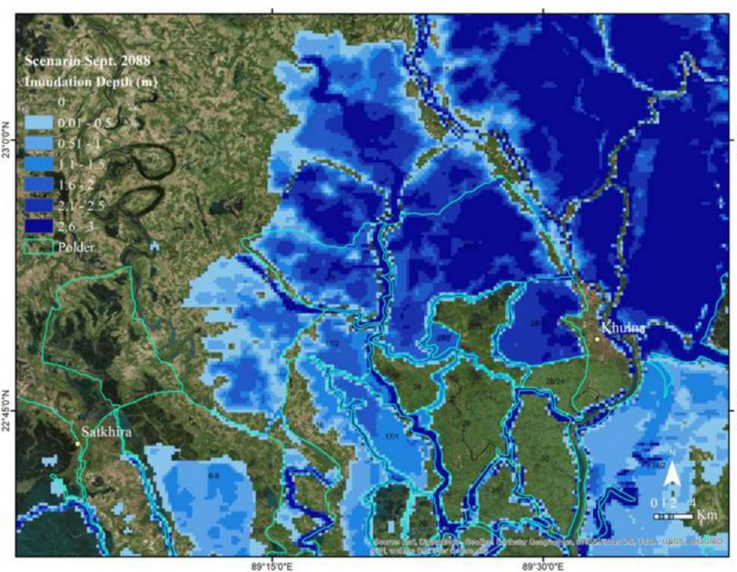

Monsoon in end-century with dredging

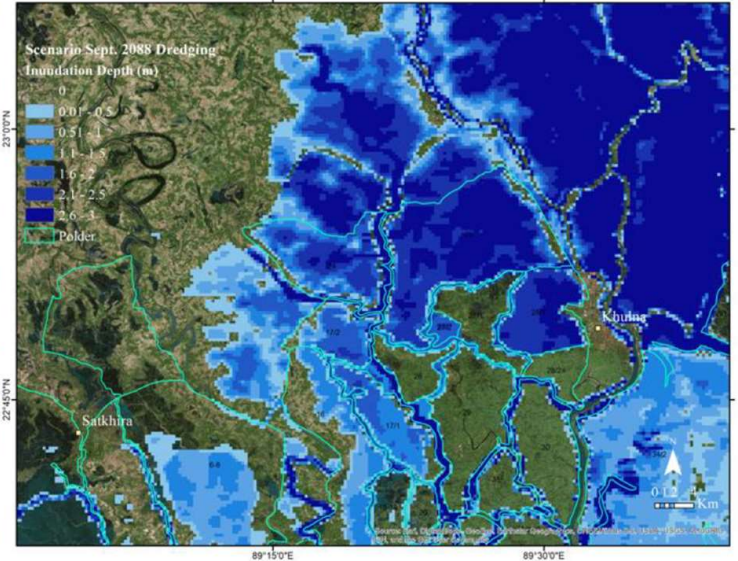

Figure 4 (k): Scenario-7: Inundation during monsoon when Hari River is not dredged (left) and when it is dredged (right). This scenario is for end-century.

Water-logging in end-century without dredging

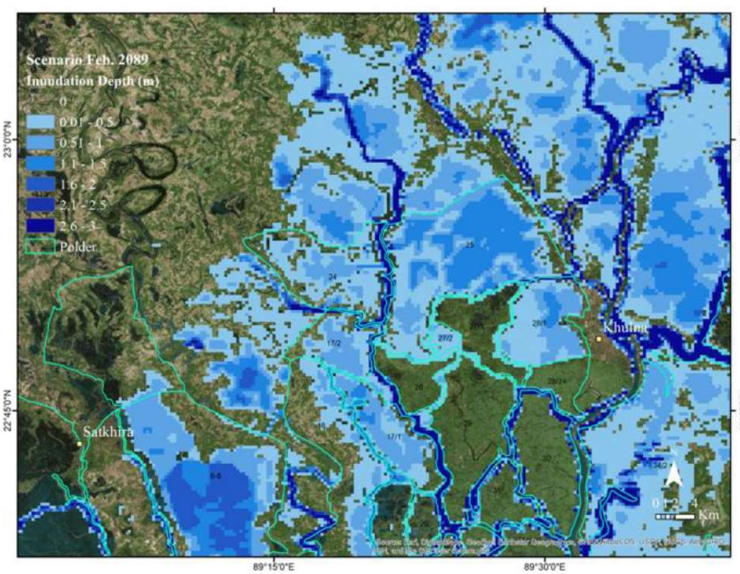

Water-logging in end-century with dredging

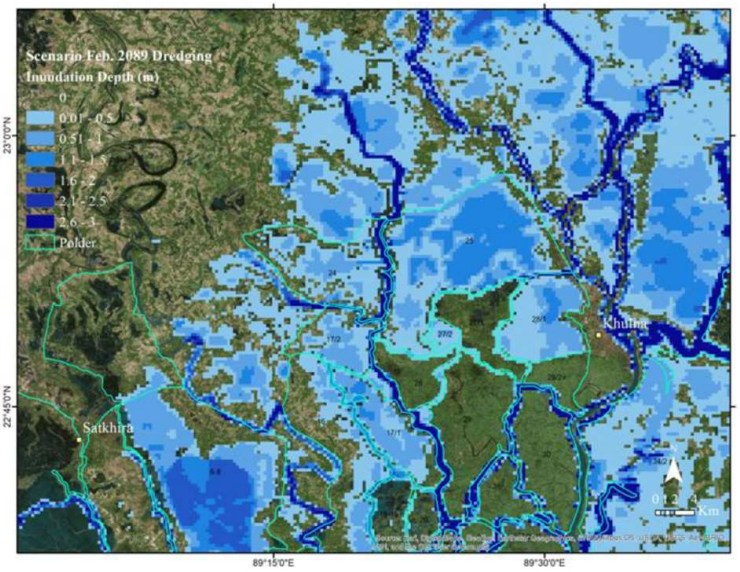

Figure 4 (I): Scenario-7: Water-logging in the study area. Water-logged condition is created during dry season of end-century. The left image shows when there is no dredging in Hari River. The right image shows when Hari River is dredged. 
Monsoon in end-century without SC polder

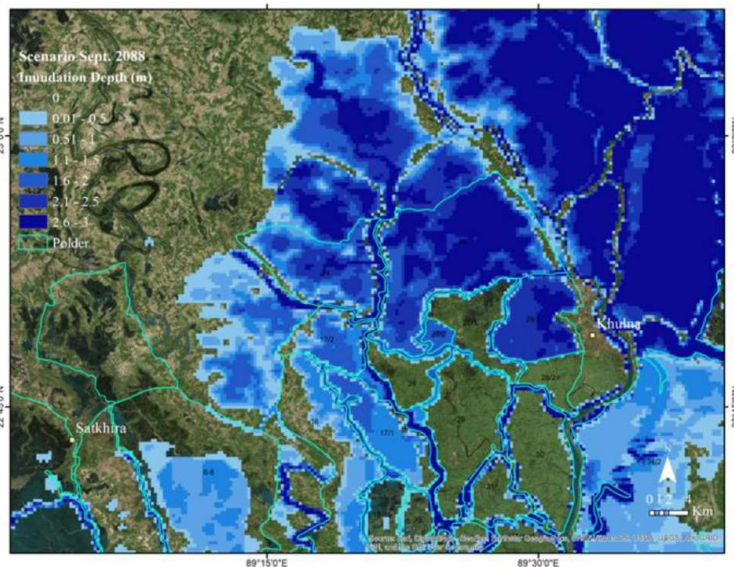

Monsoon in end-century with SC polder

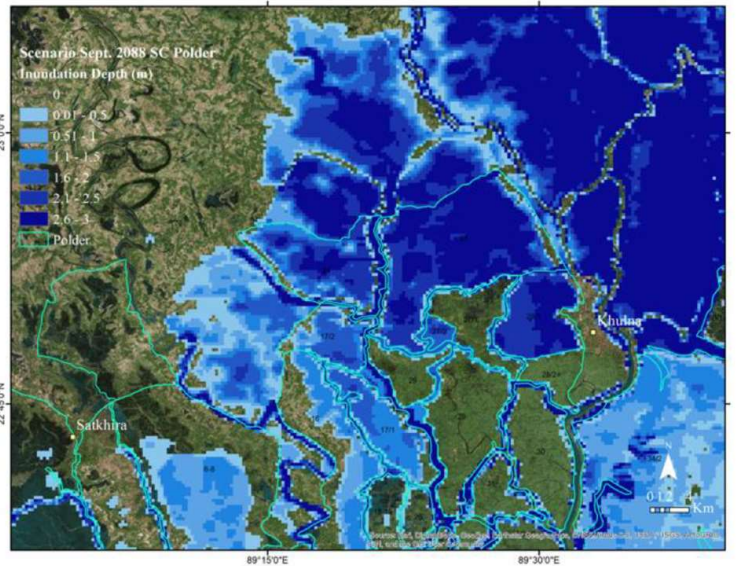

Figure 4(m): Scenario-8: Inundation during monsoon without SC polders (left) and with SC polders (right). This scenario is for end-century.

Water-logging in end-century without SC polder

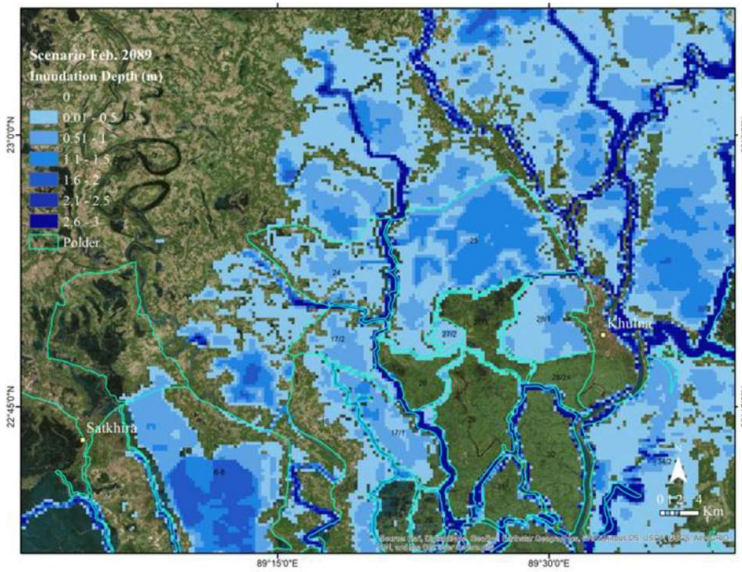

Water-logging in end-century with SC polder

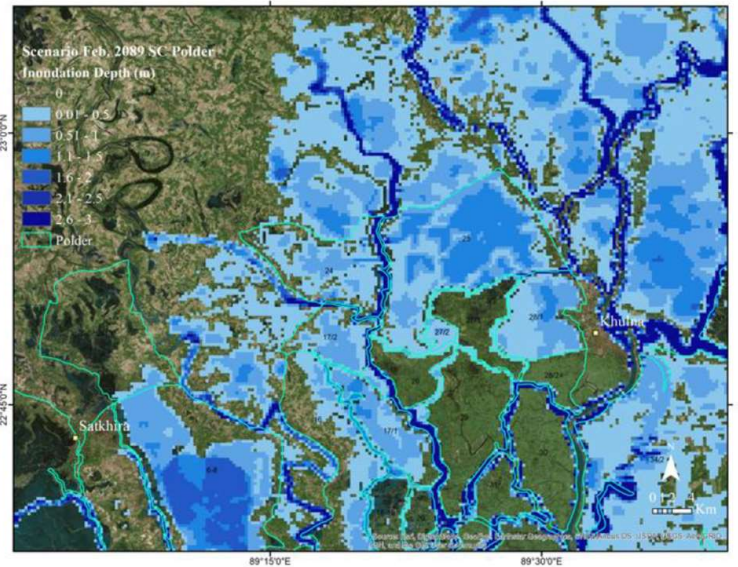

Figure 4(n): Scenario-8: Water-logging in the study area. Water-logged condition is created during dry season in end-century. The left image shows without SC polders. The right image shows with SC polders.

\section{CONCLUSIONS}

The percent of water-logged area in polder 25 is higher than polder 24 for base condition and all other scenarios. Main cause of water-logging inside polders 24 and 25 is sedimentation of the peripheral river. Model simulation results on 8 generated scenarios for water-logging inside polders 24 and 25 reveals that sedimentation in the Hari River (the river which flows in between polders 24 and 25) aggravates the water-logging situation inside the polders. Effect of sedimentation in the Hari River is confined within the floodplain of the river. Dredging of the Hari River does improve the water-logging, but the impact is confined within the floodplain of the river. If new polders are constructed in the south-central coastal region (at present there is no polder in this region), it will have little impact on the water-logging condition inside polders 24 and 25 . Towards the end of century with a sea level rise of $1.48 \mathrm{~m}$, the system becomes insensitive to any physical change of the Hari River. Sluice gate operation is a factor that influences the water logging and sedimentation input within the polder which has not been studied in this study.

\section{DECLARATION}

This is to declare that a part of this paper has been presented in ICCESD 2020 conference. 


\section{REFERENCES}

Ali M. S., Syfullah K., 2017. Effect of sea level rise induced permanent inundation on the livelihood of polder enclosed beel communities in Bangladesh: People's perception, Journal of Water and Climate Change, Vol., 8(2), 219-234.

Bangladesh Water Development Board, 2003. Khulna-Jessore Drainage Rehabilitation Project: Final Report Part A: Monitoring and Integration, Dhaka, Bangladesh.

Islam M. S., Alam R., Khan M. J. H, NurAJahan I., 2013. Methodology of crest level design of coastal polders in Bangladesh, 4th International Conference on Water \& Flood Management (ICWFM), Dhaka, Bangladesh, 9-11 March, 2013

Kay S., Caesar J., Wolf J., Bricheno L., Nicholls R.J., Islam A.K.M., Haque A., Pardaens A., Lowe, J.A. 2015. Modelling the increased frequency of extreme sea level in the Ganges-Brahmaputra-Meghna delta due to sea level rise and other effects of climate change, Environ. Sci.: Processes Impacts, 2015, 17, 1311.

Leender D. D., 2013. Tidal River Management: Temporary depoldering to mitigate drainage congestion in the southwest delta of Bangladesh MSc Thesis, Wageningen University \& Research, the Netherlands

Masud M.M.A. and Azad A.K. 2018. The role of the tidal river management for sustainable agriculture, Conference Proceedings, 2nd International Conference on Sustainable Development, 16-18 February,2018, United International University, Dhaka, pp.189-200

WARPO and IWFM, BUET, 2019. Research on the Morphological processes under Climate Changes, Sea Level Rise and Anthropogenic Intervention in the coastal zone, Final Report, March 2019

Whitehead P.G., Barbour E., Futter M. N., Sarkar S., Rodda H., Caesar J., Butterfield D., Jin L., Sinha R., Nicholls R., Salehin M.. 2015. Impacts of climate change and socio-economic scenarios on flow and water quality of the Ganges, Brahmaputra and Meghna (GBM) river systems: low flow and flood statistics, Environmental Science-Processes and Impacts, Issue 6. DOI: 10.1039/c4em00619d

(C) 2021 the JES. Journal of Engineering Science published by Faculty of Civil Engineering, Khulna University of Engineering \& Technology. This is an open access article under the terms of the Creative Commons AttributionNonCommercial-NoDerivatives License, which permits use and distribution in any medium, provided the original work is properly cited, the use is non-commercial and no Modifications or adaptations are made. 